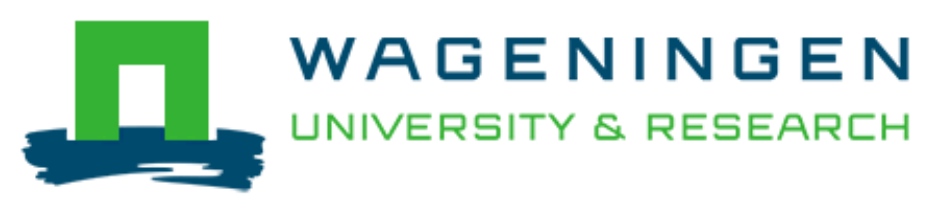

The Impact of Biofuel Policies on Crop Acreages in Germany and France Gardebroek, K., Reimer, J. J., \& Baller, L.

This article is made publically available in the institutional repository of Wageningen University and Research, under article 25fa of the Dutch Copyright Act, also known as the Amendment Taverne.

Article $25 \mathrm{fa}$ states that the author of a short scientific work funded either wholly or partially by Dutch public funds is entitled to make that work publicly available for no consideration following a reasonable period of time after the work was first published, provided that clear reference is made to the source of the first publication of the work.

For questions regarding the public availability of this article, please contact openscience.library@wur.nl.

Please cite this publication as follows:

Gardebroek, K., Reimer, J. J., \& Baller, L. (2017). The Impact of Biofuel Policies on Crop Acreages in Germany and France. Journal of Agricultural Economics, 68(3), 839-860. https://doi.org/10.1111/1477-9552.12218 


\title{
The Impact of Biofuel Policies on Crop Acreages in Germany and France
}

\section{Cornelis Gardebroek, Jeffrey J. Reimer and Lieneke Baller ${ }^{1}$}

(Original submitted June 2016, revision received November 2016, accepted February 2017.)

\begin{abstract}
A major concern about biofuels is that increasing biofuel feedstock demand reduces availability of crops for food and feed leading to higher food prices. This paper investigates relations between biofuel policies and prices of rapeseed, the major feedstock used for biodiesel production in Europe, and the impact of rapeseed prices on crop acreages in Germany and France. Biodiesel is an important biofuel in Europe, and Germany and France are the largest biodiesel producers in Europe. First, the various biofuel policies in Germany and France are discussed, followed by an analysis of their effects on rapeseed prices. Although theory indicates that such effects exist, we could not find empirical evidence for them. Second, using regional land use panel data from Germany and France we investigate empirically whether crop shares have been affected by rapeseed prices in the period 2000-2015 and whether these price effects changed because of biofuel policy changes. Results show that wheat shares in Germany and France did respond to rapeseed prices, but barley shares did not. Moreover, mandatory blending introduced in Germany in 2007 and production quotas introduced in France in 2005 led to a stronger effect of rapeseed prices on wheat shares, but again did not affect barley shares.
\end{abstract}

Keywords: Biofuel policies; crop shares; Europe; panel data; rapeseed prices.

JEL classifications: $Q 12, Q 15, Q 16, C 23$.

\section{Introduction}

In recent years the production and consumption of biofuels have increased in many European countries. Biofuel policies are often considered as an important driver for this growth. The European Union (EU) has formulated targets for the shares of bioenergy in total energy demand. To meet these targets, countries have implemented various policies such as mandatory blending of biofuels with regular fuel, tax exemptions for (the share of) biofuels, and so forth. Together these measures effectively

\footnotetext{
${ }^{1}$ Cornelis Gardebroek and Lieneke Baller are with the Agricultural Economics and Rural Policy group at Wageningen University, The Netherlands. E-mail: koos.gardebroek@wur.nl for correspondence. Jeffrey J. Reimer is with the Department of Applied Economics, Oregon State University, USA. Our thanks are due to anonymous referees for their comments on an earlier draft.
} 
raised the demand for crops that are used to a large extent in the production of biofuels, such as rapeseed which is the dominant feedstock used in European production of biodiesel, which in turn is the major biofuel produced in Europe (USDA-FAS, 2015). In theory this should have had an upward effect on the prices of these crops (Busse et al., 2012; De Gorter et al., 2013, 2015). Farmers are expected to have responded to these higher prices by extending the acreage share of biofuel feedstock crops, at the expense of crops that are predominantly used for food or feed, thereby lowering supply of the latter and raising their prices (Baffes and Haniotis, 2016). ${ }^{2}$

However, the effect of biofuel policies on European crop acreages is not clear. For a causal link between biofuel policies and crop acreages to exist two issues are important. First, biofuel policies should have led to higher prices for crops that play an important role in biofuel production such as rapeseed. Second, if these crop prices rise relatively faster than prices of crops mainly used for food or feed, farmers should respond to these higher relative prices by expanding the areas planted with these crops. Although both issues seem straightforward and plausible, it turns out that finding empirical evidence for this is not so easy, particularly for the link between biofuel policies and prices. Available price data are limited and during the years of biofuel policies, crop prices have also been affected by other factors, obscuring the effect of biofuel policies. Moreover, prices of major global commodities such as wheat are strongly influenced by international markets.

The objectives of this study are to investigate the relationship between biofuel policies and prices of rapeseed, the major feedstock used for biodiesel production in Europe, and to analyse the impact of rapeseed prices on crop acreages in Germany and France. We restrict ourselves to biodiesel because its production is more developed in Europe than ethanol production [biodiesel quantities produced exceed those of ethanol about 2 to 3 times (Sorda et al., 2010; USDA-FAS, 2015)]. Moreover, European biodiesel production is largely based on rapeseed (Hamelinck et al., 2011; USDAFAS, 2015), whereas ethanol in Europe is produced from many different feedstocks. ${ }^{3}$ Germany and France are studied because of their dominant role in biodiesel production in Europe. First, the various biofuel policies in Germany and France are discussed, followed by an analysis of their effects on rapeseed prices. Second, using regional land use panel data from Germany and France we investigate empirically whether crop shares have been affected by rapeseed prices in the period 2000-2015 and whether these price effects changed because of biofuel policy changes. For this analysis we use German regional data from 2000 to 2015 and French regional data for the period 2000-2013 to estimate crop share equations using panel data econometrics, accounting for spatial serial correlation. Specific focus is on the effect of rapeseed prices on the crop shares of wheat, barley and rapeseed and on changes in this price effect due to biofuel policies.

\footnotetext{
${ }^{2}$ Note there is no clear distinction between biofuel crops and food or feed crops, e.g. rapeseed is processed into rapeseed oil and rapemeal. The former is to a large extent used for biodiesel production, whereas the latter is used as animal feed. Wheat is mainly used for food and feed, but in recent years also 3\% of European wheat is used in ethanol production (USDA-FAS, 2015).

${ }^{3}$ Hamelinck et al. (2011) show that the feedstock composition for ethanol production in France in 2008 was $36 \%$ wheat, $16 \%$ corn, 38\% sugarbeet and $10 \%$ wine. For Germany ethanol feedstock consisted of $21 \%$ wheat, $9 \%$ corn, $5 \%$ barley, $11 \%$ rye, $2 \%$ triticale, $26 \%$ sugarbeet, $4 \%$ other and $21 \%$ unknown.
} 
This study contributes to the literature in two ways. First, we provide a panel data econometric analysis on the impact of biodiesel feedstock (rapeseed) prices on crop shares at a regional level. Most existing studies use a simulation approach to assess land use changes induced by biofuel policies (e.g. Fabiosa et al., 2010; Laborde and Valin, 2012; Timilsina et al., 2012). Notable exceptions are Langpap and $\mathrm{Wu}$ (2011) and Hausman (2012) who use regional data and econometric approaches to analyse land use changes due to biofuel policies in the US and Brazil, respectively. Econometric evidence is important since many economists and policy-makers often refer to the effect of biofuels on food prices without being able to present empirical evidence for this link relying instead on theoretical insights or indirect evidence such as price correlations (Gilbert, 2010). Brümmer et al. (2016) reviewed many recent papers discussing food price volatility and conclude that the majority of papers linking biofuel policies to food price volatility do not provide empirical evidence, whereas those that do mainly focus on market price relations without focusing on production levels or acreages. Partial and general equilibrium studies also presume the existence of this link in the models used. Econometric estimation of producer responses can provide evidence for the existence of land use changes due to biofuel policies.

Second, we provide evidence for the debate over biofuel policies on land use in Europe, which has a strong emphasis on rapeseed based biodiesel production. Whereas many studies analyse land use changes due to ethanol production in the US (e.g. Feng and Babcock, 2010; Piroli et al., 2012) or Brazil (Hausman, 2012), the evidence for Europe is rather limited. Although Banse et al. (2008), Gohin (2008) and Laborde and Valin (2012) explicitly consider the effects of European biofuel directives on land use, they only do so for the EU as a whole using computable general equilibrium (CGE) analysis, even though there are large differences in biofuel production within European countries. Kretschmer et al. (2009) and Timilsina et al. (2012) do consider various European countries and regions in their CGE analysis of biofuel targets, but these studies focus on long-run projections for 2020 instead of analysing land use changes due to current policies as done in this study. Blanco et al. (2010) use three different models to analyse effects of biofuel policies, of which two allow for EU country-specific analyses. These models also allow for analysing commodity markets and land use together. All these models focusing on Europe use a simulation approach though and often make predictions for the distant future. Our goal, by contrast, is to investigate econometrically to what extent acreages in Germany and France did respond to price changes in recent years in the light of recent biofuel policies.

In the remainder of this paper, section 2 summarises the general European biofuel policy framework and its implementation in Germany and France. Section 3 discusses the effect of biofuel policies on rapeseed prices. Section 4 focuses on the relationship between relative crop prices and crop acreages. Section 5 provides conclusions and policy implications.

\section{European Biodiesel Production and Policies Stimulating Biofuels}

\subsection{Production and trade of rapeseed, rapeseed oil and biodiesel in Germany and}

\section{France}

In line with developments worldwide, the production of biofuels has increased in Europe in recent years. However, there are substantial differences in biofuel production and policies among European countries. An interesting feature of European biofuel 
production is the importance of biodiesel production, whereas other major global biofuel producers (USA, Brazil) mainly produce ethanol. Ethanol is also produced in Europe but to a lesser extent. Historically, Germany and France have been the major producers of biodiesel in Europe. Table 1 shows biodiesel production quantities and shares in 2006 and 2014 for the top five European biodiesel producers of 2014.

Although the combined share of Germany and France went down from more than $70 \%$ in 2006 to $46 \%$ in 2014 the latter is still a sizeable share. The drop in market share can be explained by relatively new biodiesel producers such as the Netherlands and the expansion in other European countries. However, production in these countries is often based on hydrotreated vegetable oils or imported palm oil (USDA-FAS, 2015), whereas biodiesel in Germany and France is largely based on rapeseed produced domestically.

Table 2 presents production, trade and consumption figures of rapeseed and rapeseed oil for Germany, France in 2006 and 2015.

Additional data from Oilworld, ISTA Mielke GmbH indicates that in 2015 biodiesel produced in Germany was for $82 \%$ based on rapeseed oil $(11 \%$ based on used waste oils and fats, $4 \%$ based on palm oil), whereas in the same year in France $61 \%$ of biodiesel produced was based on rapeseed oil (20\% used waste oils and fats, $14 \%$ palm oil).

\subsection{Biofuel related policies}

Policies related to biodiesel production are part of more general biofuel policies in Europe. These policies exist at two different levels. At the EU level there are general policies formulated that provide a framework for individual implementation at national level, allowing individual countries to meet EU targets using different instruments. Blanco et al. (2010) distinguish four groups of instruments to stimulate biofuels: (i) budgetary support including direct support to biomass supply and tax exemptions for biofuel producers, (ii) blending or use targets (mandates), (iii) international trade measures, and (iv) measures to stimulate efficiency and productivity of the biofuel-chain. Some of these policies are set at EU level (e.g. Common Agricultural Policy (CAP) instruments and international trade measures), whereas others can be set at national level (e.g. tax exemptions and blending mandates). Next, we give a short overview of general EU policies followed by a review of specific policies implemented in Germany and France.

Table 1

European production of biodiesel in 2006 and 2014*

\begin{tabular}{lcc}
\hline & 2006 & 2014 \\
\hline Germany & $2,066(56.2 \%)$ & $3,043(27.1 \%)$ \\
France & $526(14.3 \%)$ & $2,075(18.4 \%)$ \\
The Netherlands & $16(0.4 \%)$ & $1,520(13.5 \%)$ \\
Spain & $57(1.6 \%)$ & $1,071(9.5 \%)$ \\
Poland & $82(2.2 \%)$ & $653(5.8 \%)$ \\
EU28-total & 3,674 & 11,247 \\
\hline
\end{tabular}

Notes: *In thousand tons of oil equivalent.

Source: Eurostat (2017b). 
Table 2

Balance sheet of rapeseed and rapeseed oil (1,000 ton)

\begin{tabular}{lrrrrrr}
\hline & \multicolumn{2}{c}{ Germany } & & \multicolumn{2}{c}{ France } \\
\cline { 2 - 3 } \cline { 6 - 7 } & 2006 & 2015 & & 2006 & 2015 \\
\hline Production rapeseed & 5,337 & 4,920 & & 4,144 & 5,307 \\
Net imports rapeseed (imports-exports) & 1,556 & 4,615 & & -1667 & -323 \\
Net stocks (beginning-ending stocks) & -67 & -70 & & 111 & -110 \\
Crushing of rapeseed & 6,775 & 9,330 & & 2,328 & 4,781 \\
Other use of rapeseed & 51 & 135 & & 260 & 93 \\
Production rapeseed oil & 2,679 & 4,223 & & 1,030 & 2,055 \\
Net imports rapeseed oil (imports-export) & 833 & -655 & & -268 & -150 \\
Domestic disappearance rapeseed oil* & 3,448 & 3,583 & & 762 & 1,907 \\
Use of rapeseed oil in biodiesel & 2,260 & & 2,450 & & 420 & 1,245 \\
Use of rapeseed oil for energy/heating & 100 & & 140 & & 0 & 0 \\
Use of rapeseed oil for industrial, food and other & 1,088 & & 993 & & 342 & 662 \\
\hline
\end{tabular}

Notes: "Difference between this value and sum of production plus net imports is due to small stocks.

Source: Oilworld, ISTA Mielke GmbH.

In 2003 two EU directives were formulated that provided general directions for EU biofuel policy. The 2003 EU Biofuels Directive (2003/30/EC) specified a targeted share of $2 \%$ of biofuels in total fuel use by 2005 rising to $5.75 \%$ in 2010 to be attained by all Member States, although the targets were not considered as binding (Cansino et al., 2012). By 2010 these targets were not reached, with only a $1 \%$ share in 2005 and a $4.2 \%$ share in 2010 (Sorda et al., 2010). The second important directive is the 2003 EU Energy Tax Directive (2003/96/EC), which provided a general framework for individual Member States to specify biofuel tax reductions or exemptions.

The 2009 Renewable Energy Directive (2009/28/EC), which amended and repealed the 2003 EU Biofuels Directive (2003/30/EC), specified a mandatory target for all Member States of at least $10 \%$ biofuels in transport fuels by 2020 . Sustainability requirements were also specified relating to greenhouse gas emission reductions and acceptable land use changes (Blanco et al., 2010; Sorda et al., 2010). To assure commitment with these targets, Member States had to compose national action plans for stimulating the use of bioenergy (European Parliament and Council, 2009). In 2015 the Renewable Energy Directive was revised, capping the 'share of energy from biofuels produced from cereal and other starch-rich crops, sugars and oil crops and from crops grown as main crops primarily for energy purposes on agricultural land' (European Parliament and Council, 2015) to a maximum of $7 \%$ of the final consumption of energy in transport in the Member States in 2020. This change intended to limit land use changes from food to biofuel feedstock production. The revised directive also requires countries to report on indirect land use changes due to biofuels.

Besides these specific biofuel policies the EU Common Agricultural Policy (CAP) also affected acreages of biodiesel feedstock crops. For example, in the period 19922008 production of oilseeds was supported by area payments, although the so-called Blair House Agreement in the GATT Uruguay Round negotiations, approved by the European Council in June 1993, restricted the number of hectares planted with oilseeds and eligible for area payments to about 5 million hectares. In addition set-aside 
land, which was introduced in the EU by the 1992 MacSharry reform, could be used to produce oilseed not for food or feed to the equivalent of 1 million tons of soybean meal. This planting of oilseeds on set-aside land gave an early stimulus to biodiesel production in Germany and France (Kutas et al., 2007; Bureau et al., 2010; Sorda et al., 2010) even though the biodiesel industry mainly developed after 2003. With the introduction of the Single Farm Payment in the 2003 CAP reform, the area support to oilseeds was reduced to the same level as that for cereals. However, at the same time an energy crop payment of 45 Euros per hectare grown with energy crops was introduced under the conditions that the farmer had a written contract with a biofuel producer for the supply of the crop and that the crop was not grown on set-aside land. Moreover, the total area in the EU eligible for this area payment was capped to 1.5 million hectares (Council of the EU, 2003). The CAP Health Check reform in 2008 abolished the area payments for oilseeds, including the energy crop scheme, and ended the set-aside provisions.

\subsubsection{Germany}

In line with the 2003 EU Biofuels Directive (2003/30/EC) Germany set an initial target of a $2.5 \%$ market share (in energy content) of all transport biofuels in total transport fuels for 2005, increasing to $5.75 \%$ for 2010 . However, in 2005 Germany already had a market share of $3.75 \%$ exceeding the target (Kutas et al., 2007). Since January 2007 mandatory targets for transport biofuels have been in place with specific targets for biodiesel. Over the period 2007-2013 at least 4.4\% of all diesel used in transport should have been biodiesel (Cansino et al., 2012; Rauch and Thöne, 2012). From 2014 onwards, mandates for biodiesel were based on biodiesel greenhouse gas emission savings in relation to fossil fuels (Rauch and Thöne, 2012). In 2014 the share of all biofuels in total transport fuels was $6.6 \%$ (Eurostat, 2017a).

Next to targets and mandates, Germany also stimulated production and consumption of biodiesel using tax measures complying with the 2003 EU Energy Tax Directive (2003/96/EC). From January 2004 pure biodiesel (B100) was effectively subsidised by exempting it from excise taxes. In August 2006 this policy was partly reversed by introducing a partial energy tax for pure biodiesel and a full energy tax for blends up to 5\% (Busse et al., 2012). Since January 2007 only pure biodiesel in excess of the mandate was subject to tax rebates, although these tax rebates ended in January 2013.

In 2011 additional sustainability requirements on biodiesel used in quotas were implemented in order to comply with the EU 2009 Renewable Energy Directive (2009/28/EC). Mandated biodiesel should be 35\% less carbon intensive than oil-based diesel and there are specific requirements with respect to land use changes. These sustainability criteria led to a competitive disadvantage of rapeseed-based biodiesel since it only counted once in the mandate, whereas biodiesel based on used cooking oil, animal fat or non-cellulosic matter counted double and second-generation biofuels even higher.

\subsubsection{France}

For 2005 France had a target of $1.2 \%$ biofuels in total transport fuels, but the market share in 2005 was only $0.97 \%$, slightly below the target (Kutas et al., 2007). Between 2005 and 2010 targets were gradually increased to 7\% for both ethanol and biodiesel in 2010 (Sorda et al., 2010). In July 2005 the French government adopted a National 
Energy Strategy, which included setting minimum production quota for biodiesel, 0.4 million ton in 2005 increasing to 3.1 million ton in 2010 (Kutas et al., 2007; Charles et al., 2013). These quotas are not official mandates as in Germany, but the simultaneous introduction of a general tax on polluting activities in 2005 (Taxe Générale sur les Activités Polluantes, TGAP), which fuel resellers have to pay in addition to excise taxes if they do not meet the yearly target, actually made these quotas a 'quasi-obligation system' since the high level of this tax gave fuel resellers a strong incentive to meet the targets (Kutas et al., 2007; Wiesenthal et al., 2009). Biodiesel producers tender for production quotas that are allocated for six years and non-compliance with the quota implies paying the TGAP.

Next to this combination of production quotas and TGAP, biodiesel is also partly exempted from excise taxes. However, these tax exemptions only apply to biodiesel within the production quotas and they have been reduced over time from $€ 0.33 / 1$ in 2004 to $€ 0.08 / 1$ in the period 2011-2015 (Jung et al., 2010; Charles et al., 2013).

These quota levels comply with the targets set in the EU 2009 Renewable Energy Directive (2009/28/EC). Domestic measures taken in order to comply with the Directive's sustainability criteria and progress therein are documented in yearly national progress reports (e.g. Ministry of Ecology, Sustainable Development and Energy, 2013). In 2014 the share of all biofuels in total transport fuels in France was $7.8 \%$ (Eurostat, 2017a).

\section{The Impact of Biofuel Policies on Rapeseed Prices}

\subsection{Theoretical considerations}

The theoretical effects of biofuel policies on crop prices and biofuel prices have been extensively described in, for example, Busse et al. (2012) and De Gorter et al. (2015). These studies argue that biofuel policies increase demand for biodiesel, thereby raising demand for rapeseed oil and therefore indirectly demand for rapeseed itself, which has an upward effect on rapeseed prices. However, since production of rapeseed oil from rapeseed leads to the by-product rapemeal that can be used as animal fodder, an increase in biodiesel production leads to larger supply of rapemeal, depressing its price. This implies that the upward effect of biofuel policies on rapeseed prices is reduced somewhat by the decline in rapemeal prices. Nevertheless, De Gorter et al. (2015, pp. 153-154) suggest that the positive effect of biofuel policies on feedstock prices remains.

De Gorter et al. (2015, pp. 29-35) also show a theoretical indirect effect of biofuel policies, in that they connect biofuel prices (and therefore indirectly biofuel feedstock prices) to gasoline or diesel prices, albeit in different ways for a tax credit and a blend mandate, two major biofuel policies used. A tax credit leads to a positive correlation between rapeseed and diesel prices, whereas the relationship in theory is negative for a blend mandate. The latter is due to the (slightly) upward sloping supply curve for blends. An increase in diesel prices, leads to a reduction in demand for blends, thereby reducing the demand for biodiesel and thereby rapeseed oil and rapeseed, lowering their prices.

\subsection{Biodiesel and rapeseed prices under various policy regimes}

We investigate whether biofuel policies had an impact on biodiesel and rapeseed prices in the period January 2000 to December 2015 for both countries. For Germany monthly prices for diesel, biodiesel, rapeseed oil, rapeseed and rapemeal are plotted in 
Figure 1 (see note below Figure 1 for data sources and definition). ${ }^{4}$ Note that monthly data before July 2002 were not available for biodiesel. This figure generates a number of interesting observations. First, prices of biodiesel closely follow diesel prices, as expected. Given this observation, it seems most likely that the increase of biodiesel prices since 2004 is due to the increase in diesel prices and not due to the tax exemptions introduced in 2004. This conclusion is supported by the observation that both rapeseed and rapeseed oil prices decreased somewhat after June 2004 and remained at a low level until spring 2007, a period in which biodiesel rose steadily. As discussed above, in theory the tax exemptions strengthened the correlation between diesel and biodiesel (feedstock) prices. Interestingly, when the tax exemptions were largely abolished in August 2006, the German biodiesel price rapidly dropped (Figure 1). But this coincided with a drop in conventional diesel and global crude oil prices between August 2006 and January 2007 (EIA, 2016). Rapeseed prices increased modestly in these months. So, the direct policy effects of the 2004 tax exemptions and their abolition in August 2006 did not seem to influence German rapeseed prices. The effects of these policies on biodiesel prices are more difficult to assess because they coincided with changes in global diesel and crude oil prices that in themselves already had an impact on biodiesel prices. ${ }^{5}$

A direct price effect of the mandatory blending policy introduced in January 2007 is also hard to discern from Figure 1. During this policy regime all commodity prices initially increased culminating in the 2008 price spike and the subsequent drop in prices in 2009 followed by the gradual recovery of most prices. Interestingly, the policies that seemed to have been most influential for rapeseed and rapeseed oil prices are the additional sustainability requirements for biofuels that were introduced in Germany in January 2011. Rapeseed oil became less competitive for biodiesel production compared to other biodiesel feedstocks. This is reflected in a drop in the price of rapeseed oil and, to a lesser extent, the price of rapeseed. Note that the biodiesel price itself also dropped, whereas the regular diesel price continued to increase until September 2012. After that all commodity prices started to decline, well before the phasing out of the partial tax exemptions on pure biodiesel in excess of the mandate that became effective in January 2013.

For France only monthly diesel prices and rapeseed prices were available and these are plotted in Figure 2. The French wheat price is also plotted in order to compare price movements of both commodities. The relevant French policy change was the introduction of the minimum production quotas for biodiesel in July 2005 with increasing quota levels and decreasing tax exemption rates since then. However, Figure 2 shows that the introduction of this policy did not seem to have much of an effect on French rapeseed prices. Although French rapeseed prices increased after July 2005 they followed a very similar trajectory as German rapeseed prices, for which we have

\footnotetext{
${ }^{4}$ German biodiesel prices are available from UFOP, a producer organisation aimed at promoting the use of oilseeds that was founded in 1990 by the German farmers organisation (DBV) and the organisation for plant breeders (BDP) in Germany. They publish monthly bulletins and statistics about general developments regarding biofuels. At the time of the analysis monthly UFOP reports were only available back to July 2005. However, Busse et al. (2012) provide weekly UFOP prices dating back to July 2002. These were used to calculate monthly averages for the period July 2002-June 2005.

${ }^{5}$ Given the relatively small share of biofuels in total fuel consumption, it is plausible to assume that biofuel policies have no impact on crude oil and diesel prices.
} 


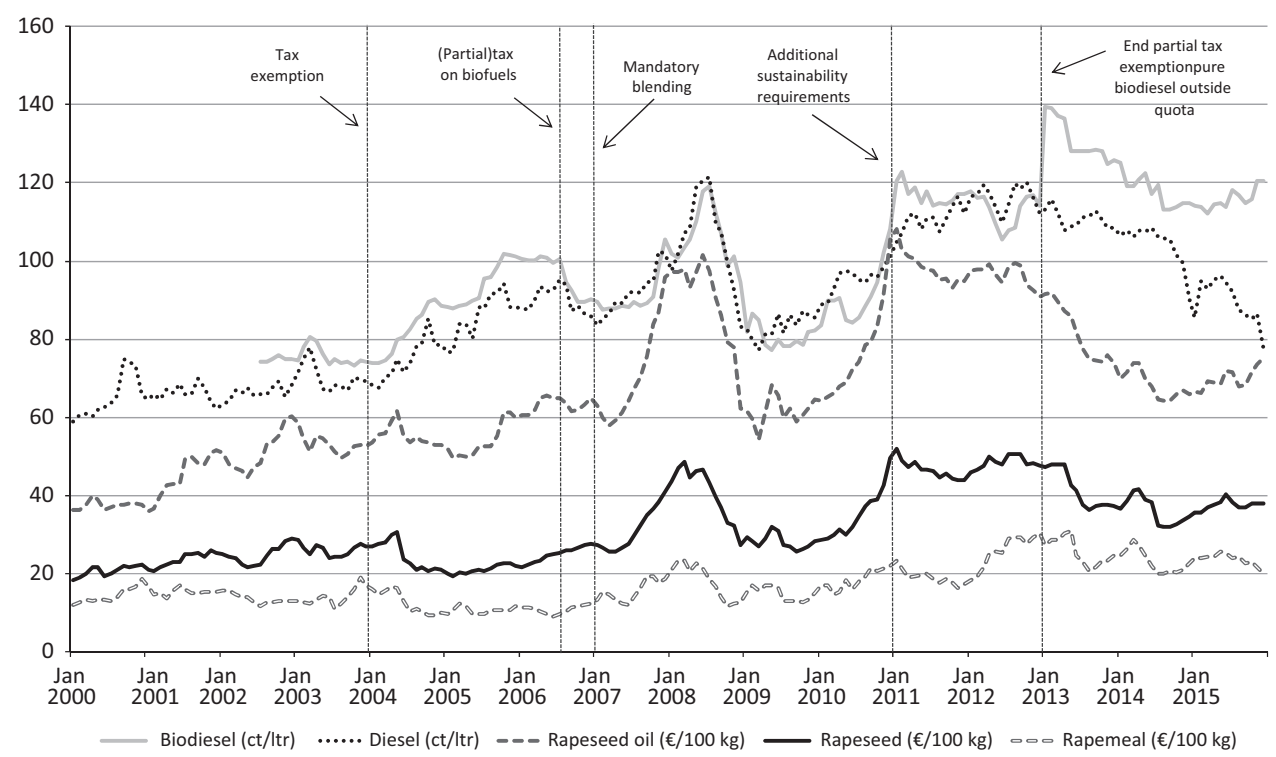

Figure 1. Prices of biodiesel, diesel, rapeseed oil and rapeseed in Germany, 2000-2015 Sources: Authors' depiction. Biodiesel prices without VAT and energy tax obtained from Busse et al. (2012) and UFOP (2016). Wholesale diesel prices obtained from German Statistical Office

(Destatis, 2016). Rapeseed (cif, Hamburg), rapeseed oil (ex-mill, Rotterdam) and rapemeal prices (34\% fob ex-mill Hamburg) obtained from Oilworld, ISTA Mielke GmbH.

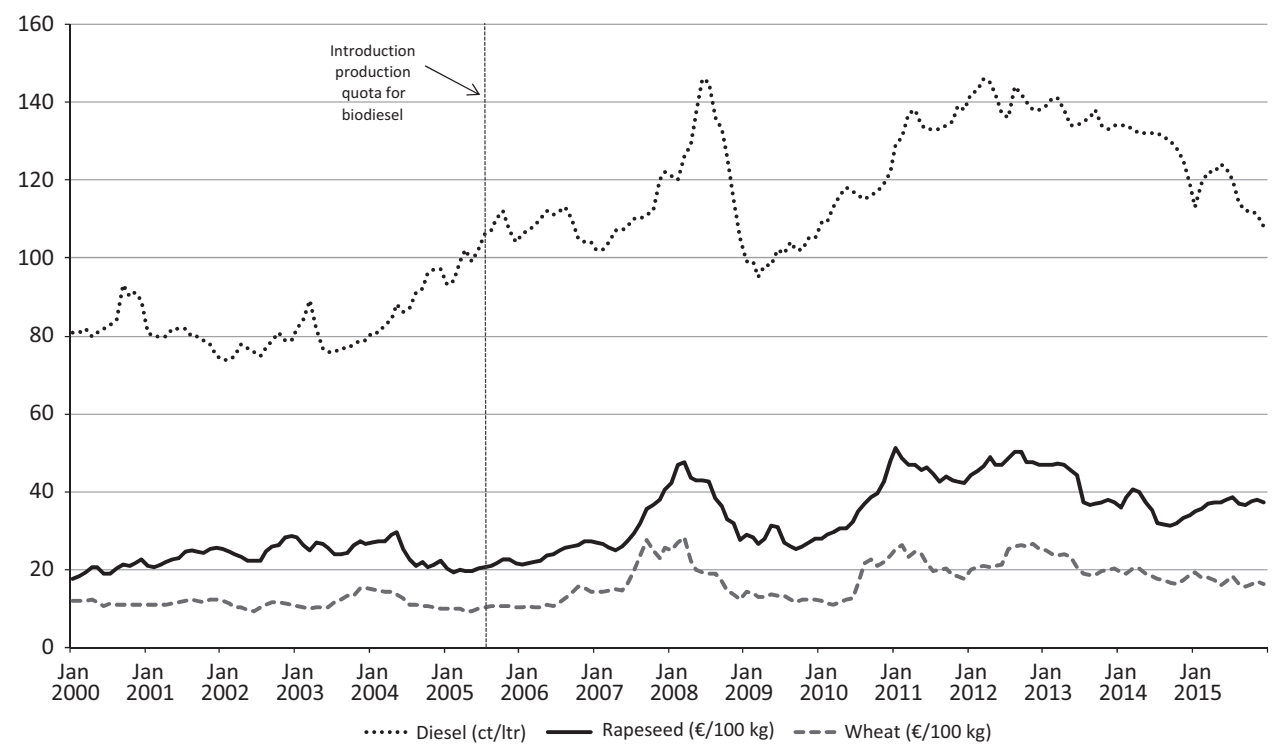

Figure 2. Prices of rapeseed, diesel and wheat in France, 2000-2015

Sources: Authors' depiction. Rapeseed and wheat prices (Rouen market) obtained from Agreste (2016). Diesel prices (consumer price metropolitan France) obtained from INSEE (2016). 
already concluded that they followed the general trend in commodity prices and not so much the German biodiesel price. ${ }^{6}$ This is confirmed by Figure 2 which shows that French rapeseed and wheat prices follow a similar trajectory both before and after the introduction of production quota. Interestingly, the price gap between rapeseed and wheat seems to widen after 2010. Nevertheless, similar to the German case, the graph does not provide much evidence for an effect of French biofuel policies on rapeseed prices.

\section{The Impact of Relative Crop Prices on Crop Acreages}

\subsection{Introduction}

Many crop prices have fluctuated dramatically in recent years. However, for farmers relative crop prices are relevant in acreage allocation decisions (e.g. Fezzi and Bateman, 2011). In this section we analyse whether acreages of major crops in Germany and France have changed due to changes in relative crop prices. In particular we focus on the effect of relative rapeseed prices on the acreage shares of wheat and barley, the two main cereals grown in both countries. Section 4.2 discusses the micro-economic framework used, section 4.3 the estimation approach, section 4.4 presents the regional panel data used in the empirical analysis and some preliminary statistics, and section 4.5 presents the estimation results of this econometric analysis.

\subsection{Micro-economic crop share model}

To analyse the effects of price changes on crop shares, a micro-economic crop share model is specified and estimated using regional data from Germany and France. Using micro-economic production theory, it is assumed that farmers in a region maximise profits, given exogenous crop prices, variable input prices, and land that can be allocated to the various crops. From this profit maximisation problem, a system of optimal acreage share equations can be derived by equating the shadow price equations for the various crop acreage shares and solving these conditions for the various shares (Moore and Negri, 1992; Wu and Segerson, 1995; Fezzi and Bateman, 2011; Kaminski et al., 2013). Let $i$ or $j$ index crops, where $i=1, \ldots, h$ and $k$ index inputs, $k=1, \ldots, K$. More formally, the land allocation problem based on an optimal profit function is written as:

$$
\pi(\mathbf{p}, \mathbf{w}, L)=\max _{s_{1}, \ldots, s_{h}}\left[\pi\left(\mathbf{p}, \mathbf{w}, L, s_{1}, \ldots, s_{h}\right)\right] \quad \text { s.t. } \sum_{i=1}^{h} s_{i}=1
$$

where $\pi$ denotes profits, $\mathbf{p}$ is a vector of crop prices, $\mathbf{w}$ is a vector of variable input prices, $L$ is total land, and $s_{i}$ are acreage shares of the various crops. For a given total area of land $L$, optimal crop shares are reflected in the equality of marginal profits with respect to shares:

\footnotetext{
${ }^{6}$ The fact that monthly French and German rapeseed prices are strongly related (correlation coefficient 0.997) is not surprising since we can expect these markets to be connected. Table 2 already showed that in this period France was a net exporter of rapeseed and Germany a net importer and since both countries are by far the largest European producers of both biodiesel and rapeseed, it is very plausible that part of the French rapeseed was exported to Germany, linking French and German rapeseed prices.
} 


$$
\frac{\partial \pi\left(\mathbf{p}, \mathbf{w}, L, s_{1}, \ldots, s_{h}\right)}{\partial s_{1}}=\frac{\partial \pi\left(\mathbf{p}, \mathbf{w}, L, s_{1}, \ldots, s_{h}\right)}{\partial s_{i}} \quad \text { for } i=2, \ldots, h .
$$

Using a flexible functional form for the profit function with prices normalised to ensure homogeneity in prices (that is, the Normalised Quadratic), this leads to a set of optimality conditions that can be solved to obtain the following reduced-form share equations:

$$
s_{i}=\alpha_{i}+\sum_{j=1}^{J} \alpha_{i j} p_{j}^{n}+\sum_{k=1}^{K} \beta_{i k} w_{k}^{n}+\delta_{i} L
$$

where superscript $n$ indicates that output and input prices are normalised by a numeraire price. Although these share equations reflect optimal cropping decisions of individual farmers, they can also be used to analyse crop allocation at a regional level since this is the aggregate of the individual crop allocation decisions. For regional data it is plausible to assume constant returns to scale per unit of land and therefore $L$ can be dropped from the equation (Fezzi and Bateman, 2011).

\subsection{Estimation approach}

Equation (3) provides a share equation for each crop, so in principle a system of share equations could be estimated for each country. We only estimate the share equations of wheat, barley and rapeseed as a function of all relevant crop prices in a country since not all crops are grown in all regions. For example, whereas sunflower is an important oilseed crop in many southern regions of France, it is not grown in northern France nor in most German regions. ${ }^{7}$ Similarly, some French regions have a zero share of sugar beet. Estimating a system of share equations for all crops in all regions would lead to many zero values for the dependent variables, which is problematic in estimation. ${ }^{8}$ Wheat, barley and rapeseed are major crops grown in all regions considered, usually together with one or more of the other crops. Moreover, the main interest in this study is investigating whether rapeseed prices affect crop shares of the main cereals wheat and barley. Therefore, share equations for wheat, barley and rapeseed are estimated for Germany and France with relevant crop prices for each country included as explanatory variables. Since we want to disentangle the own price effects of wheat and barley from rapeseed price effects, all prices are normalised by potato prices, another crop grown in all regions.

Another issue considered in estimation is the time lag in responses to crop prices. If prices are high in a certain year, farmers can only respond the year after by adjusting their cropping plan. Therefore, we use one-year lagged prices as determinants for the crop shares.

The country-specific crop share equations are estimated using observations for the various regions over multiple years. Besides output and input prices, crop shares may also vary due to other factors such as differences in climate, soil types, regional

\footnotetext{
${ }^{7}$ Sunflower is mainly used to produce cooking oil and is less suitable for biodiesel production (USDA-FAS, 2015).

${ }^{8}$ Although this could technically be solved by estimating a system of Tobit equations, this introduces another problem, i.e. the impossibility of imposing cross-equation restrictions in the resulting non-linear system of equations.
} 
policies, and the presence of a biodiesel production plant. The panel data structure allows for dealing with this unobserved heterogeneity in estimation by including regional fixed effects in the equation to be estimated:

$$
s_{i r t}=\mu_{i r}+\sum_{j=1}^{J} \alpha_{i j} p_{i j r t}^{n}+\sum_{k=1}^{K} \beta_{i k} w_{i k r t}^{n}+\varepsilon_{i r t}
$$

where $\mu_{i r}$ are regional fixed effects and $\varepsilon_{i r t}$ are residuals for region $r$ and time period $t$ in the share equation for crop $i$. Fixed effects are used instead of random-specific effects due to the limited number of regions in our dataset, making the assumption of randomly distributed specific effects implausible. ${ }^{9}$ Given that we use crop shares from neighbouring regions, the standard assumption of independent and identically distributed (i.i.d.) residuals may not be valid due to spatial autocorrelation, leading to incorrect standard errors. To test for spatial correlation we use a non-parametric test suitable for data with small $T$ as developed by Frees (1995) and implemented in Stata by De Hoyos and Sarafidis (2006). In the case of spatial correlation, standard errors robust to such cross-sectional dependence are presented (Driscoll and Kraay, 1998; Hoechle, 2007).

\subsection{Data sources, definitions and overview}

Regional data on crop acreages and input and output price indices were collected from Eurostat for different regions in Germany and France. For both countries only regions with major cropland areas were selected. A number of very small, often urban, regions were excluded. See Appendix Table A1 for a detailed list of selected regions. Data were available for 13 regions of Germany for the period 2000-2015 and 21 regions of France for 2000-2013 resulting in a dataset of 502 observations.

In calculating the crop shares we considered acreages of wheat, barley, rapeseed, potatoes, sugar beet and sunflower, the latter being only included for France. These are major crops grown by arable farmers in both countries and enable a focus on the substitution of rapeseed for wheat and barley. ${ }^{10}$ For these crops real output price indices per crop per country are used in the empirical analysis. Price indices of the following variable inputs are also used in the analysis: seeds and planting stock, energy, fertilisers and soil improvements, and plant protection products and pesticides.

Table 3 gives an overview of the data used in the empirical analysis. Acreage shares were calculated by dividing each crop area by the sum of the areas of the considered crops in a particular region and year. ${ }^{11}$

\footnotetext{
${ }^{9}$ Moreover, the price data used is at the national level so that only within variation is present. A random effects estimation procedure therefore does not lead to efficiency gains in estimation. This was reflected in very low values for between $R^{2}$ in contrast to reasonable values for within $R^{2}$. The standard panel Hausman test for fixed against random effects is therefore not applied.

${ }^{10}$ Although we could add acreages of remaining smaller crops (e.g. pulses) into a category 'Other' it is difficult to come up with a relevant price index for such an aggregate category.

${ }^{11}$ Since these calculated shares are based on only the product groups considered, these shares are not the actual shares in crop production. However, actual shares could not be obtained since there were many missing and unreliable values for total crop land in Eurostat. Acreages for these major crops are widely available and appear to be consistent.
} 
Table 3

Descriptive statistics of dependent and explanatory variables

\begin{tabular}{|c|c|c|c|c|c|c|c|c|}
\hline & \multicolumn{4}{|c|}{ Germany } & \multicolumn{4}{|c|}{ France } \\
\hline & Mean & St. dev. & Min & $\operatorname{Max}$ & Mean & St. dev. & Min & Max \\
\hline \multicolumn{9}{|l|}{ Acreage shares } \\
\hline Wheat & 0.449 & 0.050 & 0.323 & 0.625 & 0.528 & 0.149 & 0.095 & 0.763 \\
\hline Barley & 0.268 & 0.073 & 0.126 & 0.470 & 0.190 & 0.074 & 0.068 & 0.381 \\
\hline Rapeseed & 0.203 & 0.078 & 0.076 & 0.363 & 0.124 & 0.064 & 0.018 & 0.273 \\
\hline Potatoes & 0.030 & 0.029 & 0.004 & 0.125 & 0.018 & 0.024 & 0.001 & 0.108 \\
\hline Sugar beet & 0.050 & 0.030 & 0.000 & 0.120 & 0.033 & 0.048 & 0.000 & 0.183 \\
\hline Sunflower & & & & & 0.106 & 0.145 & 0.000 & 0.602 \\
\hline \multicolumn{9}{|c|}{ Normalised output price indices } \\
\hline Wheat & 0.661 & 0.182 & 0.365 & 1.000 & 1.060 & 0.205 & 0.813 & 1.430 \\
\hline Barley & 0.642 & 0.187 & 0.348 & 1.000 & 0.932 & 0.183 & 0.693 & 1.251 \\
\hline Rapeseed & 0.775 & 0.214 & 0.427 & 1.298 & 1.231 & 0.265 & 0.959 & 1.712 \\
\hline Sugar beet & 0.559 & 0.179 & 0.317 & 1.000 & 0.680 & 0.209 & 0.315 & 1.008 \\
\hline Sunflower & & & & & 1.224 & 0.255 & 0.868 & 1.676 \\
\hline \multicolumn{9}{|c|}{ Normalised input price indices } \\
\hline Energy & 0.676 & 0.174 & 0.321 & 1.000 & 1.007 & 0.188 & 0.835 & 1.370 \\
\hline $\begin{array}{l}\text { Seeds and } \\
\text { planting stock }\end{array}$ & 0.587 & 0.175 & 0.276 & 1.000 & 0.899 & 0.119 & 0.570 & 1.080 \\
\hline Fertiliser & 0.848 & 0.260 & 0.504 & 1.354 & 1.153 & 0.232 & 0.817 & 1.759 \\
\hline $\begin{array}{l}\text { Plant protection } \\
\text { and pesticides }\end{array}$ & 0.489 & 0.190 & 0.204 & 1.000 & 0.850 & 0.134 & 0.498 & 1.066 \\
\hline
\end{tabular}

Source: Eurostat $(2017 \mathrm{c}, \mathrm{d}, \mathrm{e})$ and authors' calculations.

Table 3 shows that wheat dominates arable land use with an average share of 0.449 for German regions and 0.528 for French regions. Nevertheless, the standard deviations of 0.05 for Germany and 0.149 for France show there is substantial variation in wheat shares over regions and years, particularly for France with a minimum share of 0.095 in Languedoc-Roussillon to a maximum share of 0.763 in Pays de la Loire. Barley is the second crop in both countries, followed by rapeseed.

Table 4 shows the evolution of the average calculated shares of wheat, barley and rapeseed. This table shows that for Germany as a whole the share of wheat initially was rather constant up to 2007, fluctuating between 0.419 and 0.442 but after 2008 the wheat share gradually increased up to 0.486 . The barley share on the other hand gradually declined from 2000 to 2015. The rapeseed share initially increased up to 2007 from 0.157 to 0.217 but then stabilised around 0.2 with a positive spike of 0.217 in 2013. To summarise, it seems that the growth of the rapeseed share up to 2007 and the growth in the wheat share after 2007 were both at the cost of the barley share, that has been gradually decreasing over time. For France the picture is slightly different. The share of wheat seems to have decreased over time, although there remain fluctuations. The share of barley fluctuates between 0.165 and 0.204 during the whole time period, without a clear trend. The share of rapeseed grew over time, particularly after 2004. So, for France the growth in the rapeseed share seems to be at the cost of wheat. 
Table 4

Average shares of wheat, barley and rapeseed by year

\begin{tabular}{|c|c|c|c|c|c|c|}
\hline & \multicolumn{3}{|c|}{ Germany } & \multicolumn{3}{|c|}{ France } \\
\hline & $\begin{array}{l}\text { Wheat } \\
\text { share }\end{array}$ & $\begin{array}{l}\text { Barley } \\
\text { share }\end{array}$ & $\begin{array}{c}\text { Rapeseed } \\
\text { share }\end{array}$ & $\begin{array}{l}\text { Wheat } \\
\text { share }\end{array}$ & $\begin{array}{c}\text { Barley } \\
\text { share }\end{array}$ & $\begin{array}{c}\text { Rapeseed } \\
\text { share }\end{array}$ \\
\hline 2000 & 0.431 & 0.301 & 0.157 & 0.550 & 0.172 & 0.133 \\
\hline 2001 & 0.421 & 0.307 & 0.166 & 0.522 & 0.200 & 0.127 \\
\hline 2002 & 0.429 & 0.281 & 0.185 & 0.557 & 0.187 & 0.118 \\
\hline 2003 & 0.421 & 0.295 & 0.180 & 0.525 & 0.204 & 0.126 \\
\hline 2004 & 0.437 & 0.279 & 0.181 & 0.552 & 0.186 & 0.129 \\
\hline 2005 & 0.442 & 0.272 & 0.188 & 0.547 & 0.181 & 0.139 \\
\hline 2006 & 0.432 & 0.282 & 0.199 & 0.530 & 0.184 & 0.155 \\
\hline 2007 & 0.419 & 0.269 & 0.217 & 0.522 & 0.185 & 0.176 \\
\hline 2008 & 0.447 & 0.274 & 0.191 & 0.538 & 0.191 & 0.151 \\
\hline 2009 & 0.446 & 0.260 & 0.204 & 0.506 & 0.201 & 0.158 \\
\hline 2010 & 0.468 & 0.235 & 0.209 & 0.534 & 0.172 & 0.160 \\
\hline 2011 & 0.474 & 0.234 & 0.195 & 0.532 & 0.165 & 0.166 \\
\hline 2012 & 0.457 & 0.252 & 0.196 & 0.519 & 0.180 & 0.171 \\
\hline 2013 & 0.462 & 0.232 & 0.217 & 0.531 & 0.174 & 0.153 \\
\hline 2014 & 0.474 & 0.232 & 0.206 & 0.527 & 0.186 & 0.158 \\
\hline 2015 & 0.486 & 0.241 & 0.191 & 0.534 & 0.189 & 0.155 \\
\hline
\end{tabular}

Source: Authors' calculations.

\subsection{Estimation results and discussion}

Equation (4) was estimated for the regional shares of wheat, barley and rapeseed in both Germany and France. Parameter estimates and various test statistics are presented in Table 5.

For both Germany and France, normalised rapeseed prices have a statistically significant negative effect on wheat shares. Interestingly, the normalised rapeseed price did not have a statistically significant effect on barley prices in both countries. In other words, rising rapeseed prices lead to a reduction in the share of wheat, but not in the barley share in both countries. The decline in the German barley share shown in Table 4 therefore must have had other causes. Using the average values presented in Table 3, marginal effects of a rapeseed price increase are calculated. For Germany, the average value for the normalised rapeseed price index was 0.775 , so a ceteris paribus $10 \%$ increase in the normalised rapeseed price leads to a change in the wheat crop share by $0.4 \%(-0.057 \times 0.078=-0.004)$, which is a modest effect. For France, the average normalised rapeseed price was 1.23 , so a $10 \%$ rapeseed price increase leads to reduction in the wheat share of $1.7 \%(-0.141 \times 0.123=-0.017)$.

Although we cannot compare our results with other econometric crop share studies that use nation-wide regional data, there are studies that use farm-level data. Using nation-wide rotating panel data from French grain farmers in the period 1996-2007, Carpentier and Letort (2014) found that a 10\% increase in the oilseeds price reduces the acreage of wheat by $0.5 \%$, whereas it also reduces the acreage of the aggregated category 'other cereals' by $0.6 \%$. Using a sample of French farmers from the Département de la Meuse observed between 2006 and 2009, Bayramoglu and Chakir (2016) 


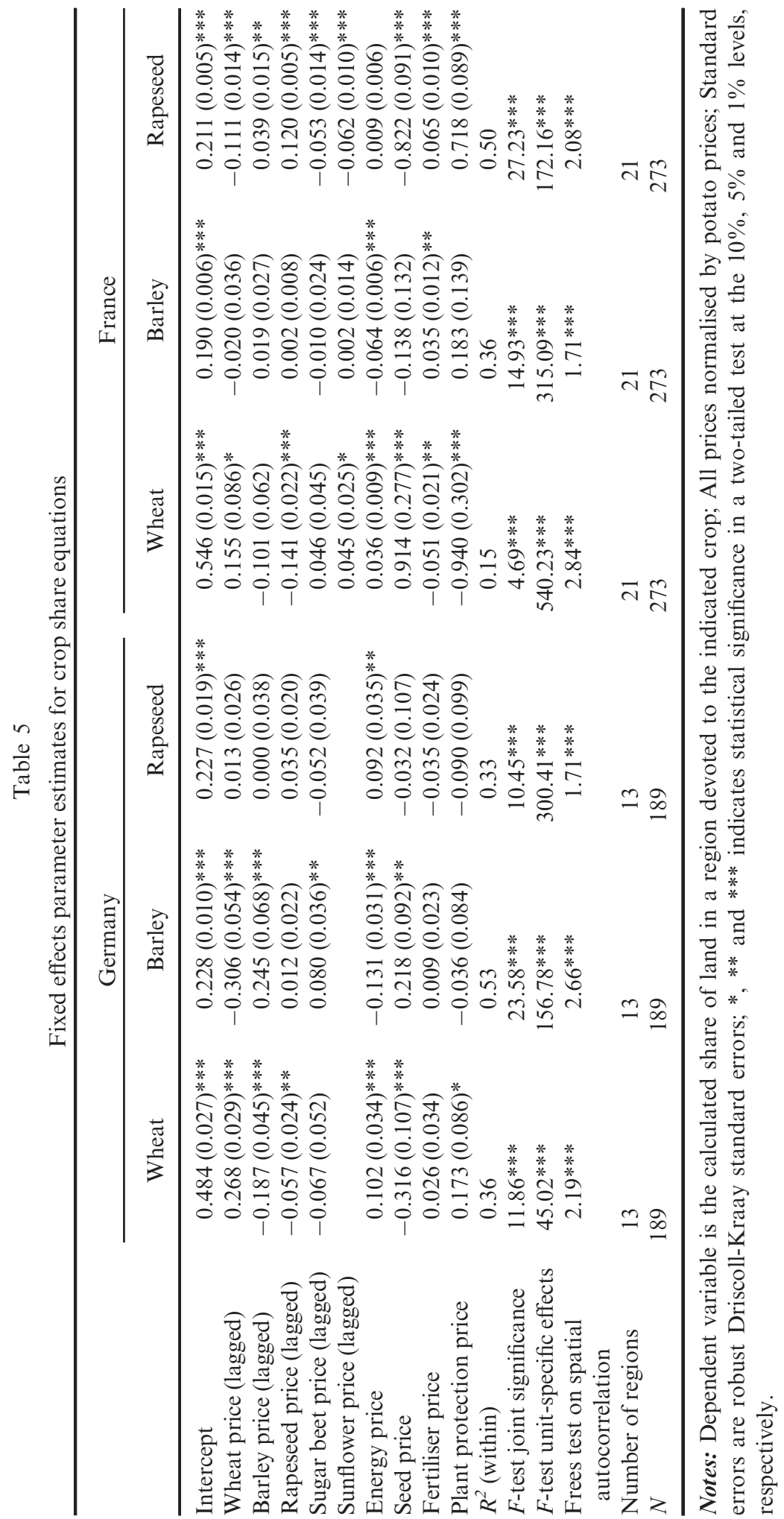




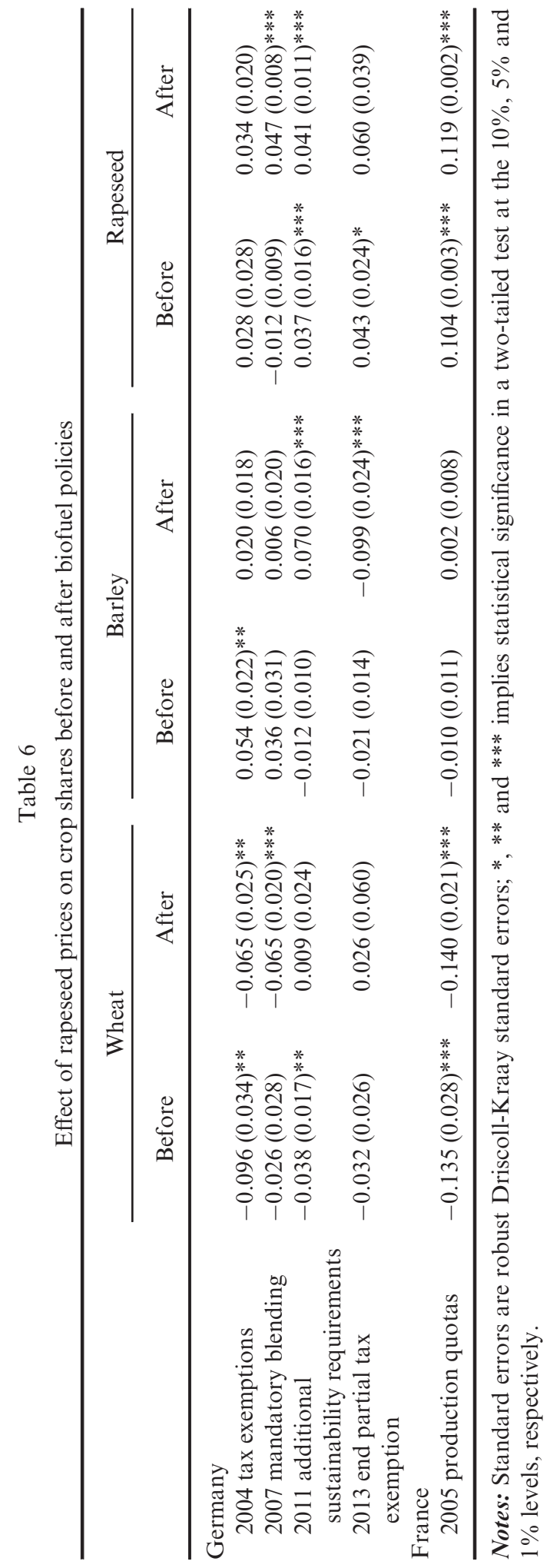


found that rapeseed prices did not affect wheat shares, but did affect barley shares, which is opposite to our results for France as a whole.

The results also show that for Germany there are statistically significant positive own price effects and negative cross-price effects for wheat and barley, but for France this is not the case. In fact, for the French barley share equation none of the normalised crop prices has a statistically significant effect on French barley shares. Concerning the rapeseed share equations we find that for Germany none of the crop prices has a statically significant effect on the rapeseed share, although the own rapeseed price parameter is positive with a $P$-value of 0.054 (one-sided test). For France we find a statistically significant own price effect of rapeseed and a counterintuitive positive price effect of barley, and also significant negative effects of wheat, sugar beet and sunflower on rapeseed shares. With respect to the included input prices results are rather mixed. There are various negative price effects, but also a number of counterintuitive positive effects. Moreover, there are differences for various shares.

Most within $R^{2}$ values are in the range 0.33-0.53, except for French wheat shares with a value of 0.15 . Accordingly, the null hypothesis that all slope parameters are jointly equal to zero is firmly rejected in all cases. The use of a fixed effects estimation approach is justified by the outcome of the $F$-tests on the region-specific effects. The null hypothesis that these effects are all similar (absence of constant regional differences) is firmly rejected in all cases. The use of Driscoll-Kraay standard errors that are robust to spatial correlation is necessary given the significant test statistics for spatial correlation among the included regions in both countries.

To investigate whether the various biofuel policies discussed in section 2 led to different effects of rapeseed prices on the crops shares, we created various interaction terms between policy dummies and rapeseed prices and re-estimated the crop share equations. Table 6 presents the biofuel policies considered, and the rapeseed price effect before and after the policy change:

The tax exemptions on biodiesel introduced in Germany in 2004 did not lead to a stronger effect of rapeseed prices on crop shares of wheat, barley, or rapeseed itself. In fact, the effect on the wheat share became weaker whereas for barley the parameter became insignificant. After the mandatory blending was introduced in Germany in 2007 the effect of rapeseed prices became statistically significant for wheat (negative effect) and rapeseed itself (positive effect), but before and after there was no effect on the barley share. The most notable change from the additional sustainability requirements introduced in 2011, which made rapeseed less competitive in biodiesel production, was that the rapeseed price did not have a significant effect on the wheat share anymore. The effect on barley became significant after 2011, but this is a counterintuitive effect. The end of the partial tax exemptions in 2013 did not seem to change the effect of rapeseed prices on shares much with the only notable change that the negative cross-price effect of rapeseed on barley became statistically significant.

For France we only considered the introduction of production quotas in 2005. Although these were gradually raised after 2005, together with declining tax exemptions, this did not lead to a fundamentally different policy. After introducing this policy the negative cross-price effect of rapeseed on the wheat share became slightly larger (statistically significant before and after), whereas the own price effect also slightly increased. The effect on the barley was statistically insignificant before and after 2005, in line with the insignificant parameter for the whole period 2000-2013. To summarise, after the introduction of this policy rapeseed prices played a slightly more 
important role in acreage decisions with respect to wheat and rapeseed, but not for barley.

Since most studies on land use in relation to biofuel policies are simulation studies, there are only a limited number of studies to compare our results with. Hausman (2012) found for Brazil that prices of sugarcane, a major input in Brazilian ethanol production, did not affect the sugarcane and soybean area. This suggests that even if Brazilian biofuel policies affected sugarcane prices, this would not affect the sugarcane area. This is different from our results of a statistically significant negative effect of rapeseed prices on wheat shares in Germany and France, but corresponds to the absence of an effect of rapeseed prices on the barley shares. Piroli et al. (2012) found that US acreages of crops used for both biofuels and food/feed (e.g. corn) respond more strongly to crude price changes than acreages of crops only used for food. This corresponds to our findings for barley where there is no effect of rapeseed prices, but our results for wheat shares show that these can also be affected by rapeseed price changes that may result from biofuel policies.

\section{Conclusions}

Since 2003 biofuel policies have been formulated within the EU and its Member States. These policies are assumed to have increased rapeseed prices due to the induced higher demand for rapeseed oil for biodiesel production. This has led to major concerns that acreages for other crops mostly unconnected with biofuel production (e.g. wheat) have been reduced, since farmers may respond to higher (relative) rapeseed prices by increasing the share of rapeseed in total acreage at the expense of wheat or barley. This study analyses the effect of biofuel policies on rapeseed prices and the responsiveness of regional shares of wheat, barley and rapeseed to rapeseed prices in Germany and France, Europe's largest biodiesel producing countries.

Although the literature shows that there is a theoretical upward effect of biofuel policies on rapeseed prices, such an effect could not be found with certainty from our analysis. Whereas biodiesel prices increased with diesel prices, the rapeseed and rapeseed oil prices did not seem to follow. One explanation for this is that European farmers already anticipated an increased demand and responded by supplying more rapeseed thereby nullifying the price effect of biodiesel prices. This is in line with the increasing share of rapeseed in both Germany and France as shown in Table 4. Another explanation is that a potential increase in demand for rapeseed in Germany and France is matched by increasing imports. Table 3 showed that rapeseed imports in Germany were much higher in 2015 than in 2006. However, for France this explanation does not hold since in both years France was a net exporter of rapeseed. We have not been able to confirm an upward effect of biofuel policies on rapeseed prices as hypothesised by economic theory.

From the crop share analysis a number of conclusions can be drawn. First, there was a negative effect of relative rapeseed prices on wheat shares in Germany and France during the study period, but not for the barley share. Of course this also implies that when rapeseed prices fell this positively contributed to the wheat share only. Second, the various policies in Germany and France and changes therein, affected these price effects differently. In Germany the mandatory blending introduced in 2007 led to a stronger negative effect of rapeseed prices on the wheat share and a stronger own positive price effect, whereas the additional sustainability requirements introduced in 2011, which made rapeseed oil less competitive for rapeseed production 
made the effect of rapeseed prices on the wheat share disappear. The production quotas introduced in France in 2005 strengthened the effect of rapeseed prices on wheat and the rapeseed share itself but only modestly.

\section{References}

Agreste. Bulletin Mensuel (Castanet Tolosan: Ministère de l'agriculture, de l'agroalimentaire et de la Forêt, 2016). Available at: http://agreste.agriculture.gouv.fr/conjoncture/le-bulletin/ article/bulletin-mensuel-8485 (last accessed 24 November 2016).

Baffes, J. and Haniotis, T. 'What explains agricultural price movements?' Journal of Agricultural Economics, Vol. 67, (2016) pp. 706-721.

Banse, M., van Meijl, H., Tabeau, A. and Woltjer, G. 'Will EU biofuel policies affect global agricultural markets?' European Review of Agricultural Economics, Vol. 35, (2008) pp. 117-141.

Bayramoglu, B. and Chakir, R. 'The impact of high crop prices on the use of agro-chemical inputs in France: A structural econometric analysis', Land Use Policy, Vol. 55, (2016) pp. 204-211.

Blanco, M., Burrell, A., Gay, H., Henseler, M., Kavallari, A., M'Barek, R., Domínguez, I. P. and Tonini, A. Impacts of the EU Biofuel Target on Agricultural Markets and Land Use: A Comparative Modelling Assessment. (European Commission Joint Research Centre, Reference Report EUR 24449. Luxembourg: Publications Office of the European Union, 2010).

Brümmer, B., Korn, O., Schlüßler, K. and Jaghdani, T. J. 'Volatility in oilseeds and vegetable oils markets: Drivers and spillovers', Journal of Agricultural Economics, Vol. 67, (2016) pp. 685-705.

Bureau, J.-C., Guyomard, H., Jacquet, F. and Tréguer, D. 'European biofuel policy : How far will public support go?' in M. Khanna, J. Scheffran and D. Zilberman (eds.), Handbook of Bioenergy Economics and Policy (New York: Springer Verlag, 2010, pp. 401-423).

Busse, S., Brümmer, B. and Ihle, R. 'Price formation in the German biodiesel supply chain: A Markov-switching vector error-correction modeling approach', Agricultural Economics, Vol. 43, (2012) pp. 545-559.

Cansino, J. M., del Pablo-Romero, M. P., Román, R. and Yñiguez, R. 'Promotion of biofuel consumption in the transport sector: An EU-27 perspective', Renewable and Sustainable Energy Reviews, Vol. 16, (2012) pp. 6013-6021.

Carpentier, A. and Letort, E. 'Multicrop production models with multinomial logit acreage shares', Environmental and Resource Economics, Vol. 59, (2014) pp. 537-559.

Charles, C., Keller, M. and Moerenhout, T. Biofuels -At What Cost? A Review of Costs and Benefits of France's Biofuel Policies. Global Subsidies Initiative of the International Institute for Sustainable Development, Geneva, 2013. Available at: https://www.iisd.org/gsi/sites/defa ult/files/bf_costeffectiveness_france.pdf (last accessed 17 November 2016).

Council of the EU. 'Council Regulation (EC) No 1782/2003 of 29 September 2003 establishing common rules for direct support schemes under the common agricultural policy and establishing certain support schemes for farmers', Official Journal of the European Union, 21 March 2003. Available at: http://eur-lex.europa.eu/legal-content/EN/TXT/PDF/?uri= CELEX:32003R1782\&from $=$ nl (last accessed 13 September 2016).

De Gorter, H., Drabik, D. and Just, D. R. 'Biofuel policies and food grain commodity prices 2006-2012: All boom and no bust?' AgBioForum, Vol. 16, (2013) pp. 1-13.

De Gorter, H., Drabik, D. and Just, D. R. The Economics of Biofuel Policies. Impacts on Price Volatility in Grain and Oilseed Markets (New York: Palgrave Macmillan, 2015).

De Hoyos, R. E. and Sarafidis, V. 'Testing for cross-sectional dependence in panel-data models', Stata Journal, Vol. 6, (2006) pp. 482-496.

DESTATIS. Daten zur Energiepreisentwicklung - Lange Reihen (Statistisches Bundesambt, Wiesbaden, 2016). Available at: https://www.destatis.de/DE/Publikationen/Thematisch/Pre ise/Energiepreise/Energiepreisentwicklung.html (last accessed 24 November 2016). 
Driscoll, J. C. and Kraay, A. C. 'Consistent covariance matrix estimation with spatially dependent panel data', Review of Economics and Statistics, Vol. 80, (1998) pp. 549-560.

EIA. Europe Brent Spot Price FOB, 2016. An online resource, available at: https://www.eia.gov/ dnav/pet/hist/LeafHandler.ash $\mathrm{x}$ n $=$ PET\&s $=$ RBRTE\&f $=M$ (Last accessed: 15 April 2016).

European Parliament and Council. 'Directive 2009/28/EC of European Parliament and of the Council of 23 April 2009 on the promotion of the use of energy from renewable sources and amending and subsequently repealing Directives 2001/77/EC and 2003/30/EC', Official Journal of the European Union (2009) pp. 16-62. Available at: http://eur-lex.europa.eu/legal-content/ $\mathrm{EN} / \mathrm{ALL} /$ ?uri $=$ celex\%3A32009L0028 (last accessed 28 February 2017)

European Parliament and Council. 'Directive (EU) 2015/1513 of the European Parliament and of the Council of 9 September 2015 amending Directive 98/70/EC relating to the quality of petrol and diesel fuels and amending Directive 2009/28/EC on the promotion of the use of energy from renewable sources', Official Journal of the European Union, L239 (2015) pp. 1-29. Available at: http://eur-lex.europa.eu/legal-content/EN/TXT/?uri =CELEX\%3A3 2015L1513 (last accessed 28 February 2017).

Eurostat. Share of Energy From Renewable Sources [nrg_ind_335a]. (Eurostat, 2017a). Available at: http://ec.europa.eu/eurostat/data/database (last accessed 28 February 2017).

Eurostat. Primary Production - All Products - Annual Data [nrg_109a]. (Eurostat, 2017b). Available at: http://ec.europa.eu/eurostat/data/database (last accessed 28 February 2017).

Eurostat. Crop Statistics by NUTS 2 Regions (from 2000 onwards) [agr_r_acs]. (Eurostat, 2017c). Available at: http://ec.europa.eu/eurostat/data/database (last accessed 28 February 2017).

Eurostat. Price Indices of Agricultural Products, Output $(2000=100)$ - Annual Data [apri_ pi00_outa]. (Eurostat, 2017d). Available at: http://ec.europa.eu/eurostat/data/database (last accessed 28 February 2017).

Eurostat. Price Indices of the Means of Agricultural Production, Input $(2000=100)$ - Annual Data [apri_pi00_ina] (Eurostat, 2017e). Available at: http://ec.europa.eu/eurostat/data/ database (last accessed 28 February 2017).

Eurostat. Crop Sstatistics by NUTS 2 Regions (from 2000 onwards) [agr_r_acs]. (Eurostat, 2017f). Available at: http://ec.europa.eu/eurostat/data/database (last accessed 28 February 2017).

Fabiosa, J., Beghin, J., Dong, J. F., Elobeid, A., Tokgoz, S. and Yu, T.-H. 'Land allocation effects of the global ethanol surge. Predictions from the international FAPRI model', Land Economics, Vol. 86, (2010) pp. 687-706.

Feng, H. and Babcock, B. A. 'Impacts of ethanol on planted acreage in market equilibrium', American Journal of Agricultural Economics, Vol. 92, (2010) pp. 789-802.

Fezzi, C. and Bateman, I. J. 'Structural agricultural land use modeling for spatial agro-environmental policy analysis', American Journal of Agricultural Economics, Vol. 93, (2011) pp. $1168-1188$.

Frees, E. W. 'Assessing cross-sectional correlation in panel data', Journal of Econometrics, Vol. 69, (1995) pp. 393-414.

Gilbert, C. L. 'How to understand high food prices', Journal of Agricultural Economics, Vol. 61, (2010) pp. 398-425.

Gohin, A. 'Impacts of the European biofuel policy on the farm sector: A general equilibrium assessment', Review of Agricultural Economics, Vol. 30, (2008) pp. 623-641.

Hamelinck, C., Koper, M., Berndes, G., Englund, O., Diaz-Chavez, R., Kunen, E. and Walden, D. Biofuels Baseline 2008 (Utrecht Ecofys), 2011. Available at: http://www.ecofys.com/files/ files/ecofys_2011_biofuels_baseline(2008).pdf (last accessed 30 November 2016).

Hausman, C. 'Biofuels and land use change: Sugarcane and soybean acreage response in Brazil', Environmental and Resource Economics, Vol. 51, (2012) pp. 163-187.

Hoechle, D. 'Robust standard errors for panel regressions with cross-sectional dependence', Stata Journal, Vol. 7, (2007) pp. 281-312. 
INSEE. Prix moyens mensuels de vente au détail en métropole, 2016. Available at: http:// www.bdm.insee.fr $/$ bdm2 $/$ affichageSeries?idbank $=000442588 \&$ page $=$ tableau\&codeGroupe $=$ $169 \&$ recherche $=$ criteres\&periodeDebut $=1 \&$ anneeDebut $=2000 \&$ periodeFin $=10 \&$ anneeFin $=$ 2016 (last accessed 24 November 2016)

Jung, A., Dörrenberg, P., Rauch, A. and Thöne, M. Biofuels - At What Cost? Government Support for Ethanol and Biodiesel in the European Union - 2010 Update (International Institute for Sustainable Development, Geneva, 2010). Available at: http://www.iisd.org/gsi/sites/defa ult/files/bf_eunion_2010update.pdf (last accessed 16 May 2015).

Kaminski, J., Kan, I. and Fleischer, A. 'A structural land-use analysis of agricultural adaptation to climate change: A pro-active approach', American Journal of Agricultural Economics, Vol. 95, (2013) pp. 70-93.

Kretschmer, B., Narita, D. and Peterson, S. 'The economic effects of the EU biofuel target', Energy Economics, Vol. 31, (2009) pp. S285-S294.

Kutas, G., Lindberg, C. and Steenblik, R. Biofuels - at What Cost? Government Support For Ethanol and Biodiesel in the European Union. (Global Subsidies Initiative of the International Institute for Sustainable Development, Geneva, 2007). Available at: http://www.iisd.org/gsi/ sites/default/files/subsidies_to_biofuels_in_the_eu_final.pdf (last accessed 7 April 2015).

Laborde, D. and Valin, H. 'Modeling land-use changes in a global CGE: Assessing the EU biofuel mandates with the MIRAGE-BioF model', Climate Change Economics, Vol. 3, (2012) pp. 1-39.

Langpap, C. and Wu, J. 'Potential environmental impacts of increased reliance on corn-based energy', Environmental and Resource Economics, Vol. 49, (2011) pp. 147-171.

Ministry of Ecology, Sustainable Development and Energy. Report on Progress in the Promotion and Use of Energy from Renewable Sources (Ministry of Ecology, Sustainable Development and Energy, Paris, 2013). Available at: http://biofuelstp.eu/country/progress-reports/ Article_22_France_report_EN.pdf (last accessed 17 November 2016).

Moore, M. R. and Negri, H. 'A multicrop production model of irrigated agriculture, applied to water allocation policy of the bureau of reclamation', Journal of Agricultural and Resource Economics, Vol. 17, (1992) pp. 29-43.

Piroli, G., Ciaian, P. and Kancs, d'. A. 'Land use change impacts of biofuels: Near-VAR evidence from the US', Ecological Economics, Vol. 84, (2012) pp. 98-109.

Rauch, A. and Thöne, M. Biofuels - At What Cost? Mandating Ethanol And Biodiesel Consumption in Germany. (International Institute for Sustainable Development, Geneva, 2012). Available at: http://www.iisd.org/gsi/sites/default/files/bf_awc_germany.pdf (last accessed 16 May 2015).

Sorda, G., Banse, M. and Kemfert, C. 'An overview of biofuel policies across the world', Energy Policy, Vol. 38, (2010) pp. 6977-6988.

Timilsina, G. R., Beghin, J. C., van der Mensbrugghe, D. and Mevel, S. 'The impacts of biofuels targets on land-use change and food supply: A global CGE assessment', Agricultural Economics, Vol. 43, (2012) pp. 315-332.

UFOP. Marktinformation Ölsaaten und Biokraftstoffe, various issues, 2016. Available at: http:// www.ufop.de/medien/downloads/agrar-info/marktinformationen (last accessed 11 April 2016).

USDA-FAS. EU Biofuels Annual. USDA-FAS GAIN report NL5028 (USDA-FAS, The Hague, 2015). Available at: http://gain.fas.usda.gov/Recent\%20GAIN\%20Publications/Biof uels\%20Annual_The\%20Hague_EU-28_7-15-2015.pdf (last accessed 10 June 2016).

Wiesenthal, T., Leduc, G., Christdis, P., Schade, B., Pelkmans, L., Govaerts, L. and Georgopoulos, P. 'Biofuel support policies in Europe: Lessons learnt for the long way ahead', Renewable and Sustainable Energy Reviews, Vol. 13, (2009) pp. 789-800.

$\mathrm{Wu}$, J. J. and Segerson, K. 'The impact of policies and land characteristics on potential groundwater pollution in Wisconsin', American Journal of Agricultural Economics, Vol. 77, (1995) pp. 1033-1047. 


\section{Appendix 1}

Table A1

German and French regions with the average size of cropland considered

\begin{tabular}{|c|c|c|c|}
\hline $\begin{array}{l}\text { Country } \\
\text { Region }\end{array}$ & $\begin{array}{l}\text { Cropland } \\
(1,000 \text { ha })^{*}\end{array}$ & Country Region & Cropland $(1,000 \mathrm{ha})^{\dagger}$ \\
\hline Germany & & France & \\
\hline 1. Baden-Württemberg & 496.65 & 14. Alsace & 58.00 \\
\hline 2. Bayern & 1171.44 & 15. Aquitaine & 173.47 \\
\hline 3. Brandenburg & 372.26 & 16. Auvergne & 196.57 \\
\hline 4. Hessen & 334.93 & $\begin{array}{l}\text { 17. Basse- } \\
\text { Normandie }\end{array}$ & 280.44 \\
\hline $\begin{array}{l}\text { 5. Mecklenburg- } \\
\text { Vorpommern }\end{array}$ & 739.50 & 18. Bourgogne & 701.24 \\
\hline 6. Niedersachsen & 988.43 & 19. Bretagne & 404.59 \\
\hline 7. Nordrhein-Westfalen & 605.36 & 20. Centre (FR) & 1364.47 \\
\hline 8. Rheinland-Pfalz & 263.95 & 21. Champagne-Ardenne & 941.86 \\
\hline 9. Saarland & 18.61 & 22. Franche-Comté & 131.12 \\
\hline 10. Sachsen & 463.53 & 23. Haute-Normandie & 410.20 \\
\hline 11. Sachsen-Anhalt & 661.16 & 24. Île de France & 421.90 \\
\hline 12. Schleswig-Holstein & 386.84 & 25. Languedoc-Roussillon & 43.24 \\
\hline \multirow[t]{9}{*}{ 13. Thüringen } & 462.13 & 26. Limousin & 41.37 \\
\hline & & 27. Lorraine & 514.26 \\
\hline & & 28. Midi-Pyrénées & 536.58 \\
\hline & & 29. Nord - Pas-de-Calais & 464.61 \\
\hline & & 30. Pays de la Loire & 493.63 \\
\hline & & 31. Picardie & 916.74 \\
\hline & & 32. Poitou-Charentes & 761.19 \\
\hline & & 33. Provence-Alpes-Côte d'Azur & 27.53 \\
\hline & & 34. Rhône-Alpes & 195.68 \\
\hline
\end{tabular}

Notes: *Total cropland is calculated by adding average land used for wheat, barley, rapeseed, potatoes, sugar beet and sunflower (France only).

The numbers for Germany and states are the averages for the years 2000-2015, for France 2000-2013.

Source: Eurostat (2017f) and authors' calculation. 